\title{
Effect of Brewery Spent Grain Level and Fermentation Time on the Quality of Bread
}

\author{
Tadlo Yitayew $\mathbb{D},{ }^{1}$ Demewez Moges $\mathbb{D},{ }^{1}$ and Neela Satheesh $\mathbb{D}^{1,2}$ \\ ${ }^{1}$ Faculty of Chemical and Food Engineering, Bahir Dar Institute of Technology, Bahir Dar University, P. O. Box 26, \\ Bahir Dar, Ethiopia \\ ${ }^{2}$ Departments of Food Nutrition and Dietetics, Faculty of Agriculture, Sri Sri University, Cuttack, Odisha, India
}

Correspondence should be addressed to Tadlo Yitayew; tadeyit1621@gmail.com

Received 11 September 2021; Revised 22 December 2021; Accepted 10 February 2022; Published 23 February 2022

Academic Editor: Ivan Salmerón

Copyright (c) 2022 Tadlo Yitayew et al. This is an open access article distributed under the Creative Commons Attribution License, which permits unrestricted use, distribution, and reproduction in any medium, provided the original work is properly cited.

BSG (brewery spent grain) is the most frequent by-product from the beer industry, which is high in protein, fiber, and minerals. This research was carried out to improve the nutritional content of bread by adding BSG to wheat flour. In this study, five levels $(0 \%, 5 \%, 10 \%, 15 \%$, and $20 \%)$ of BSG blending ratio and three levels $(1,2$, and $3 \mathrm{hrs})$ of fermentation time were considered. Standard procedures were used to determine the chemical composition of BSG, dough quality, physicochemical composition, and sensory quality of bread. The BSG is composed of $6.19 \%$ moisture, $4.01 \%$ ash, $8.80 \%$ crude fat, $16.80 \%$ crude fiber, $21.86 \%$ crude protein, $42.30 \%$ carbohydrate, $2.57 \mathrm{mg} / \mathrm{g}$ calcium, $3.16 \mathrm{mg} / \mathrm{g}$ magnesium, and $7.34 \mathrm{mg} / \mathrm{g}$ potassium. The dough water absorption (58.53-66.67 ml/100 g), development time (3.43-17.57 min), stability (6.53-12.40 min), and degree of softening (25.33$50.33 \mathrm{FU})$ were increased significantly $(p<0.05)$ as BSG ratio increased in blending. As the BSG raised, the loaf weight (127.58$148.85 \mathrm{~g}$ ) was increased and reduced the loaf volume $\left(372.97-366.74 \mathrm{~cm}^{3}\right)$. The proximate composition of the BSG blended bread was increased significantly from 33.19 to $45.29 \%$ moisture, 1.31 to $3.82 \%$ ash, 0.88 to $3.63 \%$ crude fat, 0.74 to $8.45 \%$ crude fiber, and 8.33 to $14.65 \%$ crude protein. The utilizable carbohydrate and energy values were decreased from 53.18 to $34.45 \%$ and 2.66 to $2.24 \mathrm{kcal}$, respectively. The calcium, magnesium, and potassium contents of the bread were increased from 76.44 to $150.93 \mathrm{mg} /$ $100 \mathrm{~g}, 87.12$ to $176.81 \mathrm{mg} / 100 \mathrm{~g}$, and 116.04 to $225.49 \mathrm{mg} / 100 \mathrm{~g}$, respectively, as the BSG level was increased from 0 to $20 \%$. However, the fermentation time had a significant effect $(p<0.05)$ only on the moisture content, protein content, caloric value, and mineral content of bread. The sensory acceptance of bread was significantly affected $(p<0.05)$ by BSG levels. Finally, by considering the sensory, other functional, and nutritional properties, we concluded that replacing the wheat flour with BSG up to $10 \%$ was accepted by the consumers.

\section{Introduction}

Brewery spent grain (BSG) is the main residue left after the separation of wort during the brewing process $([1,2]$; Wolfgang, 2004). Brewery spent grain is the most common brewing by-product (accounting for 85 percent) formed in the beer industry $[3,4]$. The BSG produced 31 percent of the original malt weight and 20 kilograms per 100 liters of beer [5]. The annual global production of BSG was accounted for approximately 39 million tons, around $10 \%$ produced from Europe $[6,7]$.
The BSG is composed of barley grain, husk in the largest proportion, a minor fraction of pericarp, and fragments of the endosperm. The chemical composition of BSG varies with barley variety used, malting and mashing conditions, and the quality and type of adjuncts added in the beer production process $[8,9]$. Generally, BSG is a lignocellulosic material rich in protein, fiber, and essential amino acids as well as appreciable levels of minerals, polyphenols, vitamins, and lipids $[8,10]$. The BSG contains $60-70 \%$ of the fiber, predominantly composed of cellulose and hemicelluloses together with xylose, glucose, and arabinose [11]. The BSG 
is also a good source of valuable proteins (15-26\%), including essential amino acids (lysine), representing approximately $30 \%$ of the total protein content $[12,13]$.

Waste disposal in the food industry has become a major issue for maintaining sanitation and preventing contamination of soil, air, and water in recent years. Food industrial waste contains a large concentration of carbohydrates, protein, fats, and minerals and a high value of BOD, COD, and suspended solids that attract insects, rodents, and pathogenic organisms. If BSG is not properly treated, it has a high potential to trigger serious pollution problems $[3,14]$. Brewers are currently challenged by keeping the bottomline costs low and making waste like BSG environmentally friendly by converting it into a value-added commodity due to the current global issue of the green environment [15].

The BSG is a low cost, easily available, and most valuable resource for industrial application [1]. It is an interesting raw material for both food and nonfood applications [16], including animal feed, cultivation of microorganisms, bricks production, compost preparations, and biogas productions, with the manufacture of breakfast cereals, bread, and other baked goods and snacks [4, 17-19]. The brewing process uses approved raw materials for human consumption, so that BSG is a good ingredient for developing new food products [6]. Incorporating BSG in the formulation of bakery products (bread, extrudate, and snacks) has health promoting effects, including lowering the risk of cardiovascular diseases, constipation, colon cancer, obesity, and diabetes [6, 20].

Brewing is one of the fastest growing industries in Ethiopia. The utilization of BSG is limited to animal feed, but no attention is paid to its utilization for food and nonfood applications. Since the brewing process uses materials approved for human consumption and BSG is a good source of dietary fiber, protein, fat, vitamins, and minerals, partial incorporation of BSG in formulated functional foods (biscuits, bread, cookies, and extrudates) may provide different benefits to human health $[12,20,21]$.

Bread from wheat flour is the most common and widely consumed food by all age groups. However, bread prepared from wheat flour is considered nutritionally poor. The partial replacement of wheat flour with gluten free formulations improves the nutritional quality of bakery products and satisfies consumers' demands for healthy foods [22]. Hence, the main objective of this study is to investigate the rheological property of BSG supplemented dough, the effect of different blending levels of BSG, and fermentation time on the physical properties, proximate composition, mineral composition, and sensory quality of bread.

\section{Materials and Methods}

2.1. Collection of Raw Materials and Processing. Fresh BSG was collected from Dashen Brewery, Gondar, Ethiopia, while wheat flour (First class, Merkeb Union Flour Factory), Instant Bakery Yeast (Saf-Instant, Turkey), and table salt (Iodized salt, Walia Salt Factory) were purchased from the local market (Bahir Dar city, Ethiopia). The research is con- ducted at the Food Technology laboratories in the Faculty of Chemical and Food Engineering, Bahir Dar Institute of Technology, Bahir Dar University. The water in the BSG was removed by manual hand pressing, and the remaining moisture was removed by in-house air drying at room temperature. After drying, the dried BSG was milled by local cereal mills and sieved by $355 \mu \mathrm{m}$ sieve size (Fritsch, Germany).

2.2. Experimental Design. A two-factor factorial design arranged in completely randomized design (CRD) was used in this study. The blending ratio was considered in five levels $(0 \%, 5 \%, 10 \%, 15 \%$, and $20 \%)$ and fermentation time in three levels (1, 2, and $3 \mathrm{hr})$. The entire experiment was conducted in triplicate, and the total runs were 45 .

2.3. Dough Preparation and Bread Making. The dough was prepared by adding water as per the water absorption value obtained from the farinograph results $(60-75 \mathrm{ml} / 100 \mathrm{~g}) ; 2 \%$ table salt and $1 \%$ yeast (dry ingredients) were added to the bread formulation. A laboratory scale dough mixer (HS 130 Spiral Mixer, China) was used to mix the ingredients and dough development. The resulting dough was allowed to ferment for a specified time as designed. The fermented dough was molded by hand and placed into pregreased baking trays. The baking was performed at $230^{\circ} \mathrm{C}$ for $30 \mathrm{~min}$. The baked loaves were carefully removed from the pans and allowed to cool. Furthermore, the samples were immediately used to determine proximate, mineral, and sensory analysis.

2.4. Analysis of Dough Properties. The water absorption and mixing characteristics of the composite dough samples were done using the Farinograph-E instrument (Farinograph, China) according to AACC [23]. The flour sample of $300 \mathrm{~g}$ on a $14 \%$ moisture basis was weighed and taken into a farinograph mixing bowl. Water from a burette at $30^{\circ} \mathrm{C}$ was added to the flour and mixed to form the dough. Furthermore, the farinograph was developed using the standard procedures. Water absorption, dough development time, dough stability, and degree of softening were recorded from the farinograph curves.

2.5. Determination of Bread Loaf Physical Properties. Loaf weight was determined by using an electronic digital balance with an accuracy of $0.001 \mathrm{~g}$. The loaf volume of bread was measured using the grain displacement method as reported by Makinde and Akinoso [24] with minor modification in dimension of the measuring box. A box of fixed dimensions $(22.73 \times 15.27 \times 16.21 \mathrm{~cm})$ with an internal volume of $5626.28 \mathrm{~cm}^{3}$ was filled with sorghum grains, and the total weight was noted $(C)$. The preweighed loaf $(W)$ was placed in the box, and seeds of known weight were used to fill the box to the top level. The loaf volume was determined by equations (1), (2), and (3).

$$
\text { Seed Displaced by Loaf }(L)=W+\text { Over spill weight }-C \text {, }
$$




$$
V=\frac{L * 5626.28^{3}}{C},
$$

where $V$ is the loaf volume, $L$ is the seed displaced by loaf, $C$ is the sorghum weight, and $5626.28 \mathrm{~cm}^{3}$ is the internal volume of measuring device.

Loaf specific volume was obtained by dividing the loaf volume by its corresponding weight

$$
\text { Loaf Specific Volume }=\frac{\text { Loaf Volume }\left(\mathrm{cm}^{3}\right)}{\text { Loaf Weight }(\mathrm{g})} .
$$

2.6. Proximate Analysis of BSG Flour and Bread. Proximate analysis of BSG flour and bread samples was carried out according to the AOAC [25] procedure. The moisture content was determined gravimetrically by using hot air oven method number 925.09. The ash was determined by using muffle furnace according to the AOAC method number 923.03, crude fat was determined by using Soxhlet extraction method ([25], Method: 923.03), crude fiber was determined by using nonenzymatic gravimetric method of AOAC method number 920.39, and Kjeldahl method was used for crude protein analysis according to the standard AOAC [25] method number 962.09 , respectively. The total percentage of utilizable carbohydrate content was determined by the difference method. The gross energy was calculated according to equation (4).

$$
\begin{aligned}
\text { Energy, } \mathrm{kcal}= & (\text { Crude Fat } * 9)+(\text { Crude Protein } * 4) \\
& +(\text { Utilizable carbohydrate } * 4) .
\end{aligned}
$$

2.7. Mineral Analysis. The concentrations of calcium and magnesium in bread samples were measured by an atomic absorption spectrophotometer (Perkin-Elmer, Model 3100, USA) (Gimblet et al., 1966) after wet digestion of $1 \mathrm{~g}$ sample [26]. From the resulting sample solution, $10 \mathrm{ml}$ was taken in to $50 \mathrm{ml}$ conical flask and mixed with $4 \mathrm{ml}$ of concentrated nitric acid and diluted with deionized water up to the calibration mark. From the resulting sample solution, $10 \mathrm{ml}$ was measured in a $50 \mathrm{ml}$ conical flask and mixed with $2 \mathrm{ml}$ of molybdate solution, $4 \mathrm{ml}$ of concentrated nitric acid, and $4 \mathrm{ml}$ hydrazine sulphate and heated in a water bath at $60^{\circ} \mathrm{C}$ until a blue color was developed. A standard stock solution of calcium, magnesium, and potassium was prepared by appropriate dilution of stranded pure metals. The absorbance of calcium, magnesium, and potassium was measured at $422.7 \mathrm{~nm}$, $285.2 \mathrm{~nm}$, and $830 \mathrm{~nm}$ wavelengths, respectively. The concentration of the sample solution is obtained according to the standard curve. The concentration of the phosphorus content was determined by UV-vis spectrophotometer (Cary $60 \mathrm{UV}-\mathrm{Vis}$, Malaysia) after wet digestion of $1 \mathrm{~g}$ of sample according to the procedure of Ganesh et al. [27].

2.8. Sensory Evaluation. The prepared breads were coded randomly with three digits. The samples are provided to the untrained panelists for sensory evaluation. The panelists were asked to give the sensory scoring by considering the color, flavor, taste, crumb texture, and overall acceptability of the bread using a nine-point hedonic scale according to the method reported by Ikuomola et al. [28].

2.9. Data Analysis. The Analysis of Variance (ANOVA) was conducted to determine the difference between the treatments by using the Statistical Analysis System (SAS) software (9.1.3) with the general linear model. The mean comparison was done by Duncan multiple range test, and significance was considered at $p \leq 0.05$.

\section{Results and Discussion}

3.1. Proximate and Mineral Composition of BSG. The results on proximate composition and mineral composition are presented in Table 1. As seen from the table, BSG is a good source of fat, fiber, and protein with minerals in trace amounts. The ash content was $4.01 \%$, the crude fat content was $8.79 \%$, the crude fiber content was $16.95 \%$, and the crude protein content was $21.86 \%$ with $2.50 \mathrm{mg} / \mathrm{g}$ calcium, $3.10 \mathrm{mg} / \mathrm{g}$ magnesium, and $7.40 \mathrm{mg} / \mathrm{g}$ potassium content. Different studies are $[9,13,29]$ conducted on brewery spent grain and concluded that BSG is a good source of protein, fat, ash, and dietary fiber. There was a slight variation in the composition of the crude protein, crude fat, crude fiber, and ash content of the BSG in different reported studies. This variation may be attributed to the barley variety, maturity of the barley used in the process, malting and mashing conditions, quality, and type of adjuncts added [9]. In general, protein and fibers are dominantly available in BSG. The carbohydrate content of BSG is lower than that of barley due to the extensive amylolysis process of mashing. The BSG is also a good source of trace metals. The reports of Madubuike and Okolo [30]; Waters et al. [13] showed that BSG had a high concentration of calcium, magnesium, and phosphorus and trace amounts of zinc and iron.

3.2. The Farinograph Property of Dough. Table 2 depicts the effect of BSG level on the water absorption, dough development time, dough stability, and degree of softening.

The water absorption was increased significantly $(p<0.05)$ from 58.40 to $66.67 \mathrm{ml} / 100 \mathrm{~g}$ as the BSG level was increased from 0 to $20 \%$. An increase in the water absorption of the BSG blended wheat flour was attributed to the presence of high protein and nonstarchy polysaccharides (fibers) in the BSG. The work of Steinmacher et al. [31] and Stojceska and Ainsworth [6] reported that the water absorption increases from 58 to $61 \%$ with $10 \%$ BSG addition and $63.70-72.30 \%$ with $12 \%$ BSG addition, respectively. The higher fiber content of BSG and high protein content of BSG provide high water absorption and consequently provide good baking performance $[10,32]$.

Similarly, the dough development time was also increased from 3.43 to $17.57 \mathrm{~min}$ as the BSG level increased from 0 to $20 \%$. This may be attributed to the high fiber and protein content of BSG, prolonging the dough development time. However, the dough stability and degree of softening were not increased linearly. The dough stability and degree of softening were initially increased from 6.53 to $12.40 \mathrm{~min}$ 
TABle 1: Proximate and mineral composition (\% dry matter) of brewery spent grain.

\begin{tabular}{lc}
\hline Physicochemical composition & Values (\%) \\
Moisture content & $6.09 \pm 0.77$ \\
Ash & $4.01 \pm 0.25$ \\
Crude fat & $8.79 \pm 0.33$ \\
Crude fiber & $16.95 \pm 0.45$ \\
Crude protein & $21.86 \pm 0.31$ \\
Carbohydrate & $42.30 \pm 0.47$ \\
Mineral composition & Values (mg/g) \\
Calcium & $2.57 \pm 0.01$ \\
Magnesium & $3.16 \pm 0.02$ \\
Phosphorus & $7.34 \pm 0.02$ \\
\hline
\end{tabular}

Values are presented as mean \pm standard deviation of triplication.

and 25.33 to $50.33 \mathrm{FU}$, respectively. In contrast, the dough stability and degree of softening were decreased to $9.90 \mathrm{~min}$ and $45.33 \mathrm{FU}$ by the addition of 15\% BSG, and the result was not detected at $20 \%$ BSG level. These trends in dough stability and degree of softening are attributed to the long mixing time and high shear force applied in addition to the high fiber and protein content. Steinmacher et al. [31] reported that dough made with composite flours had longer development time and lower stability compared to wheat flour dough. The study of Stojceska and Ainsworth [6] also reported an increase in dough development time and dough stability and a decrease in the degree of softening when wheat flour is blended with BSG.

The dough development time depends on the water absorption speed of flour constituents to form a smooth and homogenous appearance. At the same time, strong wheat has higher water absorption, good extensibility, longer dough development time, and stability [10]. Longer development time indicates that the dough was developed slowly when additional fiber and protein were present in the flour. The decrease in dough stability and degree of softening may be attributed to the high interference between the protein and fiber content in dough. Generally, the addition of high fiber content raw materials may affect the dough properties significantly [33].

3.3. The Physical Properties of Bread. The ANOVA showed that BSG had a significant effect $(p<0.05)$ on the loaf weight, loaf volume, and specific volume of bread loaf as presented in Table 3. The loaf weight was increased from 127.58 to $148.85 \mathrm{~g}$ as the BSG level was increased from 0 to $20 \%$. This incensement in loaf weight was attributed to the high fiber and protein content in the BSG. As the BSG level increased in the dough, the water absorption capacity increased, and it leads to the reduction in the carbon dioxide holding capacity of the dough. The works of Mongi et al. [34] and Mudau et al. [35] also reported the increase in bread loaf weight by the addition of high fibrous ingredients in the dough.
The loaf volume and specific loaf volume of bread were decreased from 372.97 to $366.74 \mathrm{~cm}^{3} / \mathrm{g}$ and 2.89 to $2.46 \mathrm{~cm}^{3} / \mathrm{g}$, respectively, as the BSG level was increased from 0 to $20 \%$. This trend may be attributed to the interaction between fiber and protein and leads to weakening of the gluten network of the dough and reduces the gas holding capacity of the dough. Amoriello et al. [36] and Ktenioudaki et al. [37] showed that the specific volume of bread loaves was decreased as the BSG addition in bakery product formulation. The high fiber content of BSG reduces product volume and elasticity during the dough preparation $[33,38]$.

In this study, fermentation time had a nonsignificant effect $(p<0.05)$ on the weight, volume, and specific volume of bread loaves. This was attributed to the presence of high fiber content in the BSG, and this fiber enhances the water absorption of the dough and weakens the gluten network and gas holding capacity of the bread loaves. In contrast, Aplevicz et al. [39] reported that as the fermentation time was increased, the loaf volume of bread also increased significantly.

3.4. The Proximate Composition of Bread. The results in Table 4 showed the effect of BSG level and fermentation time on the nutritional quality of bread. The level of BSG addition had a significant effect $(p<0.05)$, while fermentation time had a nonsignificant effect $(p>0.05)$ on the bread proximate composition.

The moisture content of bread was significantly affected $(p<0.05)$ by the BSG level, and it was increased from 33.19 to $45.29 \%$ as the BSG level increased from 0 to $20 \%$. This may be attributed to the presence of high fiber content of BSG, the baking temperature, and time. The fiber absorbs higher quantities of water during mixing and leading to high water retention capacity. Similarly, the work of Fărcaş et al. [12] showed that the moisture content of the bread was reported higher as the BSG level was increased. The baking temperature and time affect the starch gelatinization and which in turn affect the moisture content of the bread [40]. The fermentation time significantly $(p<0.05)$ reduced the moisture content of bread as the fermentation time was increased from 1 to $3 \mathrm{hr}$. This decreasing trend in moisture content of bread may be attributed to the evaporation of water from the dough surface during the extended fermentation duration. The work of Siddiqi et al. [41] also showed that the moisture content of the bread was decreased as the fermentation time was increased.

The BSG level also had a significant effect $(p<0.05)$ on the ash content of bread. It increased from 1.19 to $3.82 \%$ as the BSG level was increased from 0 to $20 \%$. This may be attributed to the presence of higher amounts of minerals in the cereal grains. Musa et al. [42] indicated the addition of bran increases the ash content of the bread. Similarly, whole grain bakery products are reported to be rich in ash content.

The crude fat content of bread was significantly $(p<0.05)$ increased from 0.88 to $3.83 \%$ as the BSG level was increased from 0 to $20 \%$. This may be due to the BSG contains part of the barley germ, and usually, the cereal germ is rich in fat content. The work of Fărcaş et al. [12] and Ktenioudaki et al. [37] 
TABLE 2: Farinograph properties (water absorption, dough development time, dough stability, degree of softening) of dough prepared from the blend of wheat and BSG flours.

\begin{tabular}{lcccc}
\hline BSG level, \% & $\begin{array}{c}\text { Water absorption } \\
(\mathrm{ml} / 100 \mathrm{~g})\end{array}$ & $\begin{array}{c}\text { Dough development } \\
\text { time }(\mathrm{min})\end{array}$ & Dough stability (min) & Degree of softening (FU) \\
\hline 0 & $58.40 \pm 1.16 \mathrm{a}$ & $3.43 \pm 0.21 \mathrm{a}$ & $6.53 \pm 0.15 \mathrm{a}$ & $25.33 \pm 2.51 \mathrm{a}$ \\
5 & $59.53 \pm 1.25 \mathrm{a}$ & $4.60 \pm 0.20 \mathrm{~b}$ & $11.60 \pm 0.10 \mathrm{c}$ & $36.00 \pm 2.64 \mathrm{a}$ \\
10 & $62.23 \pm 1.09 \mathrm{~b}$ & $6.96 \pm 0.58 \mathrm{c}$ & $12.40 \pm 0.91 \mathrm{c}$ & $50.33 \pm 4.72 \mathrm{c}$ \\
15 & $65.18 \pm 1.48 \mathrm{c}$ & $8.93 \pm 1.00 \mathrm{~d}$ & $9.90 \pm 0.70 \mathrm{~b}$ & $45.33 \pm 2.52 \mathrm{c}$ \\
20 & $66.67 \pm 1.13 \mathrm{c}$ & $17.57 \pm 0.40 \mathrm{e}$ & $\mathrm{ND}$ & $\mathrm{ND}$ \\
$\begin{array}{l}\text { f values (BSG level* } \\
\text { fermentation durations) }\end{array}$ & $<0.0001$ & $<0.0001$ & $<0.0001$ & $<0.0001$ \\
\hline
\end{tabular}

The values are mean \pm standard deviation of three observations. ND: not determined. Means followed by different letters within the column show statistically significant difference $(p<0.05)$.

TABLE 3: Physical properties of the bread prepared with different levels of BSG and fermentation durations.

\begin{tabular}{|c|c|c|c|c|}
\hline BSG level (\%) & Fermentation time (hr) & Loaf weight $(\mathrm{g})$ & Loaf volume $\left(\mathrm{cm}^{3}\right)$ & Specific loaf volume $\left(\mathrm{cm}^{3} / \mathrm{g}\right)$ \\
\hline \multirow{3}{*}{0} & 1 & $129.31 \pm 1.23 \mathrm{a}$ & $370.61 \pm 4.45 \mathrm{abcd}$ & $2.87 \pm 0.05 \mathrm{ef}$ \\
\hline & 2 & $129.12 \pm 2.99 a$ & $372.85 \pm 2.09 \mathrm{bcd}$ & $2.89 \pm 0.07 f$ \\
\hline & 3 & $127.58 \pm 3.32 \mathrm{a}$ & $372.97 \pm 3.89 \mathrm{bcd}$ & $2.92 \pm 0.08 \mathrm{f}$ \\
\hline \multirow{3}{*}{5} & 1 & $135.89 \pm 1.52 b$ & $368.86 \pm 3.69 \mathrm{ab}$ & $2.71 \pm 0.03 \mathrm{~d}$ \\
\hline & 2 & $133.74 \pm 1.81 b$ & $373.45 \pm 1.30 \mathrm{ab}$ & $2.79 \pm 0.04 \mathrm{e}$ \\
\hline & 3 & $133.60 \pm 1.38 b$ & $374.57 \pm 1.41 \mathrm{~d}$ & $2.80 \pm 0.03 \mathrm{e}$ \\
\hline \multirow{3}{*}{10} & 1 & $142.64 \pm 2.72 c$ & $369.48 \pm 1.96 \mathrm{abc}$ & $2.59 \pm 0.05 b c$ \\
\hline & 2 & $142.44 \pm 3.41 \mathrm{cde}$ & $369.82 \pm 1.27 \mathrm{abc}$ & $2.60 \pm 0.07 b c$ \\
\hline & 3 & $141.84 \pm 2.52 \mathrm{~cd}$ & $371.16 \pm 0.97 \mathrm{abcd}$ & $2.62 \pm 0.04 c$ \\
\hline \multirow{3}{*}{15} & 1 & $146.38 \pm 1.67 \mathrm{ef}$ & $368.58 \pm 0.88 \mathrm{a}$ & $2.51 \pm 0.03 \mathrm{a}$ \\
\hline & 2 & $145.83 \pm 1.60 \mathrm{cdef}$ & $368.62 \pm 0.3 .17 \mathrm{a}$ & $2.53 \pm 0.03 \mathrm{ab}$ \\
\hline & 3 & $145.24 \pm 0.48 \mathrm{def}$ & $371.07 \pm 0.06 \mathrm{abcd}$ & $2.56 \pm 0.13 \mathrm{dab}$ \\
\hline \multirow{3}{*}{20} & 1 & $148.85 \pm 1.24 \mathrm{f}$ & $366.74 \pm 0.45 a$ & $2.46 \pm 0.36 \mathrm{a}$ \\
\hline & 2 & $148.82 \pm 0.63 f$ & $368.23 \pm 0.53 \mathrm{ab}$ & $2.47 \pm 0.84 \mathrm{a}$ \\
\hline & 3 & $148.14 \pm 1.63 \mathrm{f}$ & $369.33 \pm 2.42 \mathrm{abc}$ & $2.49 \pm 1.48 \mathrm{a}$ \\
\hline \multicolumn{2}{|c|}{$p$ values (BSG level ${ }^{*}$ fermentation durations) } & $<0.0001$ & 0.0090 & $<0.0001$ \\
\hline
\end{tabular}

The values are mean \pm standard deviation of three observations. Means followed by different letters within the column show statistically significant difference $(p<0.05)$.

also showed that the fat content of the baked products is increased as the BSG level increased.

The bread crude fiber and protein contents were increased from 0.74 to $8.45 \%$ and 8.33 to $14.45 \%$, respectively, as the BSG level increased from 0 to $20 \%$. This may be attributed to the brewing process is focusing more on starch hydrolysis and little on proteolysis; thus, BSG is a good source of fiber and protein. Previous studies [5, 30, 43] also showed that BSG is rich in fiber and proteins. The study of Fărcaş et al. [12] and Stojceska and Ainsworth [6] showed that BSG addition increased the crude fiber and protein content of the bakery product.

The fermentation time also had a significant effect $(p<0.05)$ on the protein content of the bread. It was increased from 11.95 to $12.71 \%$ as the fermentation time was increased from 1 to $3 \mathrm{hr}$. This increment may be attributed to the loss of dry matter during fermentation and degradation of complex proteins by microbial action, and proteins may be produced as a by-product of the fermenta- tion process. Similerly, Day and Morawicki [44] and Nkhata et al. [45] also reported an increment of protein continents as fermentation time extends in fermented foods.

The utilizable carbohydrate and calorific value of bread were decreased from 53.93 to $35.07 \%$ and 2.60 to $2.28 \mathrm{kcal}$, respectively, as the BSG composition increased. This trend may be attributed to the mashing operation during the brewing process which is aimed to hydrolysis of starch into fermentable sugar [13], which reduces the carbohydrate content in the BSG. The calorific value is the sum of crude fat, protein, and utilizable carbohydrate content with their multiplication factor. Thus, the caloric value also reduces accordance with the carbohydrate content.

3.5. The Mineral Content of Bread. As shown in Table 5, both the BSG level and fermentation time had a significant effect $(p<0.05)$ on the mineral content of the bread. The calcium, magnesium, and potassium contents of the bread were increased from 76.44 to $150.93 \mathrm{mg} / 100 \mathrm{~g}, 87.12$ to 


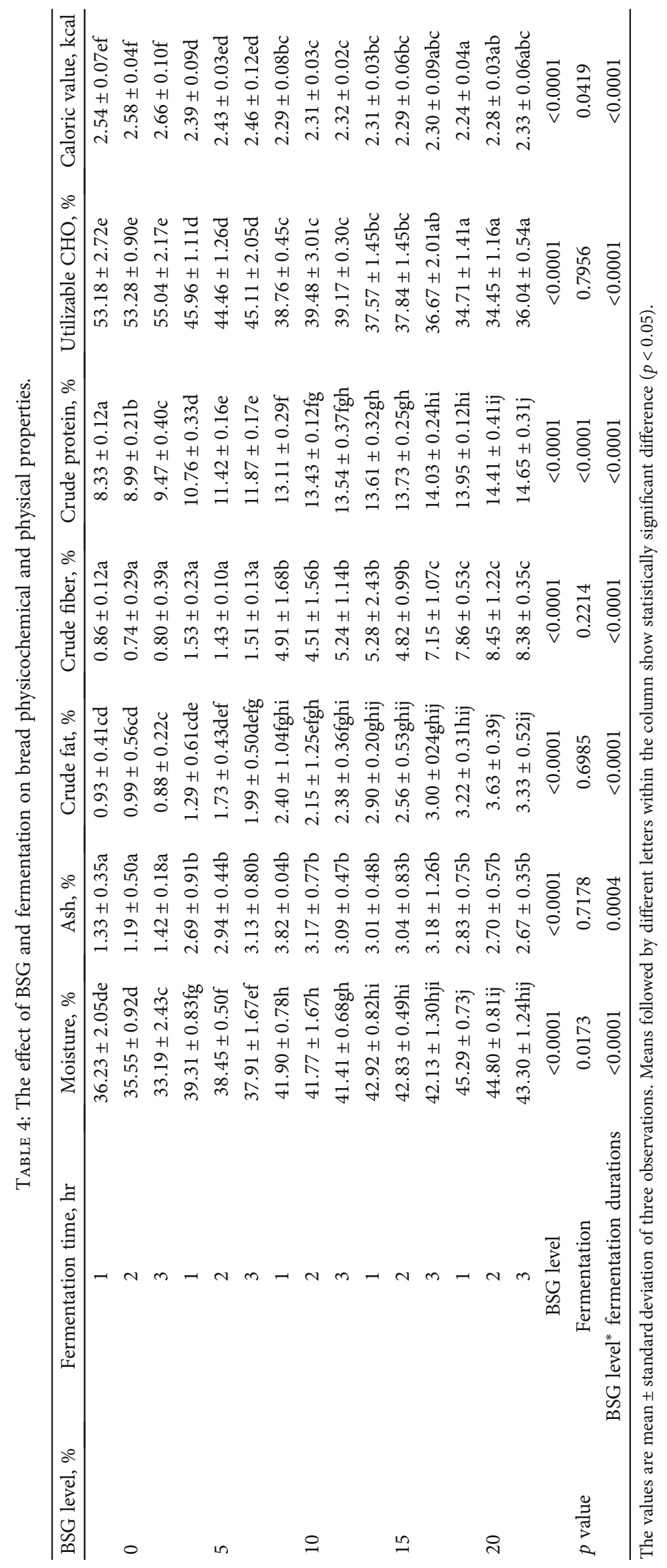


TABLE 5: The mineral content (calcium, magnesium, phosphorus) of BSG incorporated bread.

\begin{tabular}{|c|c|c|c|c|}
\hline BSG level (\%) & Fermentation time (hr) & Calcium, mg/100 g & Magnesium, mg/100 g & Phosphorus, mg/100g \\
\hline \multirow{3}{*}{0} & 1 & $76.44 \pm 2.55 \mathrm{a}$ & $87.12 \pm 1.12 \mathrm{a}$ & $116.04 \pm 2.45 \mathrm{a}$ \\
\hline & 2 & $79.74 \pm 0.55 \mathrm{ab}$ & $91.05 \pm 0.54 \mathrm{ab}$ & $120.86 \pm 0.01 b$ \\
\hline & 3 & $81.07 \pm 1.55 b$ & $93.00 \pm 1.25 b$ & $123.04 \pm 0.21 b$ \\
\hline \multirow{3}{*}{5} & 1 & $90.11 \pm 1.47 \mathrm{c}$ & $102.07 \pm 0.13 c$ & $135.12 \pm 0.89 c$ \\
\hline & 2 & $95.90 \pm 1.90 \mathrm{~d}$ & $103.82 \pm 0.58 c$ & $140.15 \pm 0.88 \mathrm{~d}$ \\
\hline & 3 & $103.77 \pm 2.04 \mathrm{e}$ & $104.30 \pm 0.46 c$ & $145.71 \pm 1.67 \mathrm{e}$ \\
\hline \multirow{3}{*}{10} & 1 & $111.94 \pm 2.14 \mathrm{f}$ & $110.34 \pm 1.64 \mathrm{~d}$ & $155.19 \pm 2.52 \mathrm{f}$ \\
\hline & 2 & $118.41 \pm 1.03 \mathrm{~g}$ & $115.93 \pm 2.25 \mathrm{e}$ & $163.23 \pm 2.19 \mathrm{~g}$ \\
\hline & 3 & $122.74 \pm 1.87 \mathrm{~h}$ & $117.69 \pm 1.11 \mathrm{e}$ & $167.29 \pm 1.98 \mathrm{~g}$ \\
\hline \multirow{3}{*}{15} & 1 & $130.31 \pm 1.25 \mathrm{i}$ & $140.91 \pm 3.88 \mathrm{f}$ & $187.81 \pm 3.42 \mathrm{~h}$ \\
\hline & 2 & $133.00 \pm 1.72 \mathrm{i}$ & $145.83 \pm 1.93 \mathrm{~g}$ & $192.88 \pm 2.44 \mathrm{i}$ \\
\hline & 3 & $139.26 \pm 0.45 j$ & $151.18 \pm 2.07 \mathrm{~h}$ & $200.62 \pm 1.68 \mathrm{j}$ \\
\hline \multirow{3}{*}{20} & 1 & $143.07 \pm 0.96 \mathrm{k}$ & $161.30 \pm 2.82 \mathrm{i}$ & $209.91 \pm 1.25 \mathrm{k}$ \\
\hline & 2 & $147.02 \pm 0.271$ & $170.47 \pm 2.96 \mathrm{i}$ & $218.66 \pm 1.801$ \\
\hline & 3 & $150.93 \pm 2.42 \mathrm{~m}$ & $176.81 \pm 2.07 \mathrm{k}$ & $225.49 \pm 3.00 \mathrm{~m}$ \\
\hline \multirow{3}{*}{$p$ value } & BSG level & $<0.0001$ & $<0.0001$ & $<0.0001$ \\
\hline & Fermentation time & $<0.0001$ & $<0.0001$ & $<0.0001$ \\
\hline & BSG level* fermentation durations & $<.0001$ & $<.0001$ & $<.0001$ \\
\hline
\end{tabular}

The values are mean \pm standard deviation of three observations. Means followed by different letters within the column show statistically significant difference $(p<0.05)$.

$176.81 \mathrm{mg} / 100 \mathrm{~g}$, and 116.04 to $225.49 \mathrm{mg} / 100 \mathrm{~g}$, respectively, as the BSG level was increased from 0 to $20 \%$. This may be attributed to that BSG levels as it is a good source of minerals.

The BSG is mainly composed of the husk of grain and minerals in cereals present in the outer layer of their husk. The reports of Ikram et al. [46] and Waters et al. [13] also confirmed that BSG is rich in calcium, magnesium, potassium, and other minerals in trace amount. The study of Fărcaş et al. [12] showed an increased content of mineral from $0.44 \%$ to $1.29 \%$ for bread with $20 \%$ BSG addition. The work of Sharif et al. [47] also indicates that the addition of defatted rice bran can also increase the mineral content of cookies significantly. In addition, Tizazu et al. [48] also showed that germination or preprocessing of cereal grains could reduce the phytate level and increase the mineral bioavailability.

Similarly, the fermentation time also had a significant effect $(p<0.05)$ on the mineral content of the bread. The calcium, magnesium, and potassium contents of the bread were increased from 110.37 to $119.55 \mathrm{mg} / 100 \mathrm{~g}, 120.35$ to $128.59 \mathrm{mg} / 100 \mathrm{~g}$, and 160.81 to $172.43 \mathrm{mg} / 100 \mathrm{~g}$, respectively, as the fermentation time was increased from 1 to $3 \mathrm{hr}$. This may be attributed to the fact that fermentation of food products improves the nutritional quality as well as the bioavailability of minerals by the breakdown of oxalates and phytates. The work of Buta and Emire [49] showed that fermentation had a significant effect on the mineral content of soybean blends of weaning food. On the other hand, the work of Ojokoh et al. [50] on the breadfruit and cowpea blend flours showed that fermentation reduces the oxalate and phytate content. The work of Assohoun et al. [51] also showed that fermentation improved the mineral content
(Ca, Mg, P, Z, Fe, etc.) of fermented foods as the phytate level decreased and loss of dry matter as the fermenting yeast utilizes the carbohydrate and protein.

3.6. Sensory Acceptability of BSG Incorporated Bread. As showed in Table 6, the sensory acceptance of the bread prepared from wheat and BSG flour at different levels was decreased significantly $(p<0.05)$ as the BSG level was increased from 0 to $20 \%$. The panelist score for bread color was decreased significantly $(p<0.05)$ from 7.58 to 5.58 . The color of the bread appears darker as the BSG flour substitution level was increased from 0 to $20 \%$. This may be due to the dark brown color of BSG flour and the high fiber content of BSG. The study conducted by Lukinac et al. [52] and Petrović et al. (2015) on bread and cookies also reported that the color of the product turns darker as the substitution level of BSG flour was increased as they measured the color of the product instrumentally.

The taste and flavor of the bread were also negatively affected $(p<0.05)$ by the addition of higher levels of BSG. The panelists were given the sensory score of 7.63-6.05 and 8.00-6.05 for taste and flavor, respectively, out of ninepoint hedonic scale. This trend may be attributed to the BSG; it is a poor source of sugar as the sugar is extracted, and cooked malt flavor is also developed during the mashing process. The study of Ikuomola et al. [28] showed that panelist score for taste and flavor was decreased as the level of malted barley increased in the baked foods.

The crumb texture was also significantly affected $(p<0.05)$ by the BSG level. The panelist score was decreased from 7.95 to 5.58 as the BSG level was increased from 0 to $20 \%$. The crumb texture appeared rough, harder, and 
TABLE 6: Sensory evaluation results of bread prepared by addition of BSG on 9-point hedonic scale.

\begin{tabular}{|c|c|c|c|c|c|c|}
\hline BSG level (\%) & Fermentation time (hr) & Color & Taste & Flavor & Crumb texture & Overall acceptance \\
\hline \multirow{3}{*}{0} & 1 & $7.37 \pm 0.60 c$ & $7.63 \pm 0.49 b$ & $7.53 \pm 0.61 b$ & $7.47 \pm 0.61 \mathrm{de}$ & $7.42 \pm 0.51 \mathrm{a}$ \\
\hline & 2 & $7.58 \pm 0.51 c$ & $7.53 \pm 0.61 b$ & $7.68 \pm 0.58 b$ & $7.95 \pm 0.40 \mathrm{e}$ & $7.53 \pm 0.51 \mathrm{a}$ \\
\hline & 3 & $7.47 \pm 0.51 c$ & $7.63 \pm 0.49 b$ & $8.00 \pm 0.47 b$ & $7.73 \pm 0.45 \mathrm{de}$ & $7.74 \pm 0.45 b$ \\
\hline \multirow{3}{*}{5} & 1 & $7.26 \pm 0.99 c$ & $7.42 \pm 0.84 b$ & $7.53 \pm 0.90 b$ & $7.53 \pm 1.02 \mathrm{de}$ & $7.63 \pm 0.83 b$ \\
\hline & 2 & $7.32 \pm 1.00 c$ & $7.16 \pm 0.69 b$ & $7.58 \pm 0.77 b$ & $7.37 \pm 0.90 \mathrm{~d}$ & $7.53 \pm 0.61 b$ \\
\hline & 3 & $7.21 \pm 0.71 c$ & $7.26 \pm 0.87 b$ & $7.63 \pm 0.89 b$ & $7.37 \pm 0.68 \mathrm{~d}$ & $7.32 \pm 0.67 b$ \\
\hline \multirow{3}{*}{10} & 1 & $7.05 \pm 0.62 c$ & $7.63 \pm 0.76 b$ & $7.63 \pm 0.96 b$ & $7.47 \pm 1.02 \mathrm{de}$ & $7.53 \pm 0.84 b$ \\
\hline & 2 & $7.05 \pm 0.40 c$ & $7.53 \pm 0.61 b$ & $7.74 \pm 0.73 b$ & $7.42 \pm 0.90 \mathrm{de}$ & $7.74 \pm 0.56 b$ \\
\hline & 3 & $7.16 \pm 0.69 c$ & $7.37 \pm 0.83 b$ & $7.93 \pm 0.71 b$ & $7.42 \pm 0.77 \mathrm{de}$ & $7.47 \pm 0.51 b$ \\
\hline \multirow{3}{*}{15} & 1 & $5.95 \pm 0.78 b$ & $6.32 \pm 0.67 a$ & $6.21 \pm 0.92 \mathrm{a}$ & $6.42 \pm 0.69 c$ & $6.42 \pm 0.61 \mathrm{a}$ \\
\hline & 2 & $6.21 \pm 0.79 b$ & $6.11 \pm 0.57 \mathrm{a}$ & $6.58 \pm 0.61 \mathrm{a}$ & $6.21 \pm 0.79 b$ & $6.05 \pm 0.52 \mathrm{a}$ \\
\hline & 3 & $5.58 \pm 0.84 \mathrm{a}$ & $6.26 \pm 0.73 a$ & $6.05 \pm 0.85 \mathrm{a}$ & $6.26 \pm 0.56 \mathrm{bc}$ & $6.26 \pm 0.73 a$ \\
\hline \multirow{3}{*}{20} & 1 & $5.84 \pm 0.69 \mathrm{ab}$ & $6.11 \pm 0.74 \mathrm{a}$ & $6.11 \pm 0.86 \mathrm{a}$ & $5.68 \pm 0.67 \mathrm{a}$ & $6.21 \pm 0.63 \mathrm{a}$ \\
\hline & 2 & $5.58 \pm 0.69 \mathrm{a}$ & $5.95 \pm 0.52 \mathrm{a}$ & $6.05 \pm 0.78 \mathrm{a}$ & $5.84 \pm 0.69 \mathrm{ab}$ & $6.16 \pm 0.60 \mathrm{a}$ \\
\hline & 3 & $6.26 \pm 0.65 b$ & $6.05 \pm 0.62 \mathrm{a}$ & $6.16 \pm 0.51 \mathrm{a}$ & $6.21 \pm 0.71 b$ & $6.37 \pm 0.59 \mathrm{a}$ \\
\hline$p$ value & BSG level* fermentation durations & $<0.0001$ & $<0.0001$ & $<0.0001$ & $<0.0001$ & $<0.0001$ \\
\hline
\end{tabular}

The values are presented in mean \pm standard deviation of 50 observations. Means followed by different letters within the column show statistically significant difference $(p<0.05)$.

cracked. This may be attributed to the presence of high fiber, and protein absorbs much water causing harder bread structure. The addition of fiber-rich ingredients increases the hardness of the product (Petrović et al., 2015; [6]). The overall acceptability of bread was decreased significantly $(p<0.05)$ from 7.74 to 6.05 as the BSG level was increased from 0 to $20 \%$. This may be attributed to the cumulative effect of color, taste, flavor, and crumb texture. Similarly, different scientists $[12,13,53,54]$ reported that the addition of BSG significantly alters the sensory acceptance of different baked products.

\section{Conclusion}

The composite bread from BSG and wheat flours was developed and analyzed to assess the effect of BSG level and fermentation time on the nutritional value of bread. The BSG is nutrient rich, and its utilization in food application will enhance the economic potential of the brew house as well as improving the nutritional value of bread. The BSG level significantly affects $(p<0.05)$ the dough properties, the proximate composition, mineral content, and sensory acceptance of bread. The ash, crude fat, crude fiber, and crude protein of the bread were increased from 1.31 to $3.82 \%, 0.88$ to $3.63 \%$, 0.74 to $8.45 \%$, and 8.33 to $14.65 \%$, respectively, as the BSG level increased from 0 to $20 \%$. Similarly, the calcium, magnesium, and potassium content of the bread was increased from 76.44 to $150.93 \mathrm{mg} / 100 \mathrm{~g}, 87.12$ to $176.81 \mathrm{mg} / 100 \mathrm{~g}$, and 116.04 to $225.49 \mathrm{mg} / 100 \mathrm{~g}$, respectively, as the BSG level was increased from 0 to $20 \%$, while the carbohydrate content and the sensory acceptance were significantly affected by the BSG level. The fermentation time also significantly increased the protein, calcium, magnesium, and potassium content of the bread from 11.95 to $12.71 \%, 110.37$ to $119.55 \mathrm{mg} / 100 \mathrm{~g}$,
120.35 to $128.59 \mathrm{mg} / 100 \mathrm{~g}$, and 160.81 to $172.43 \mathrm{mg} / 100 \mathrm{~g}$, respectively, as the fermentation time was increased from 1 to $3 \mathrm{hr}$. BSG is a rich source of protein and fiber, and incorporating BSG flour in bakery products has a health promoting effect. However, the addition of high amount of BSG flour negatively affects the physical properties and sensory acceptance of bread. We can conclude from this study that the optimum BSG flour level in bread formulation never exceeds $10 \%$.

\section{Data Availability}

All the data is included in the manuscript.

\section{Conflicts of Interest}

The authors declare that they have no conflicts of interest.

\section{References}

[1] S. Aliyu and M. Bala, "Brewer's spent grain: a review of its potentials and applications," African Journal of Biotechnology, vol. 10, no. 3, pp. 324-331, 2011.

[2] C. Boulton, "Encyclopaedia of Brewing," Brewing-Encyclopaedias, Wiley Publisher, 2013, https://kataloge.uni-hamburg.de/ $\mathrm{DB}=2 / \mathrm{SET}=1 / \mathrm{TTL}=6 / \mathrm{SHW}$ ?FRST $=1$.

[3] O. Malomo, "The use of brewer's spent grains in the cultivation of some fungal isolates," International Journal of Nutrition and Food Sciences, vol. 2, no. 1, p. 5, 2013.

[4] W. Russ, H. Mörtel, and R. Meyer-Pittroff, "Application of spent grains to increase porosity in bricks," Construction and Building Materials, vol. 19, no. 2, pp. 117-126, 2005.

[5] J. Steiner, S. Procopio, and T. Becker, "Brewer's spent grain: source of value-added polysaccharides for the food industry in reference to the health claims," European Food Research and Technology, vol. 241, no. 3, pp. 303-315, 2015. 
[6] V. Stojceska and P. Ainsworth, "The effect of different enzymes on the quality of high-fibre enriched brewer's spent grain breads," Food Chemistry, vol. 110, no. 4, pp. 865-872, 2008.

[7] M. Verni, E. Pontonio, A. Krona et al., "Bioprocessing of brewers' spent grain enhances its antioxidant activity: characterization of phenolic compounds and bioactive peptides," Frontiers in Microbiology, vol. 11, no. July, pp. 1-15, 2020.

[8] J. A. Robertson, K. J. A. I’Anson, J. Treimo et al., "Profiling brewers' spent grain for composition and microbial ecology at the site of production," LWT - Food Science and Technology, vol. 43, no. 6, pp. 890-896, 2010.

[9] M. Santos, J. J. Jiménez, B. Bartolomé, C. Gómez-Cordovés, and M. J. Del Nozal, "Variability of brewer's spent grain within a brewery," Food Chemistry, vol. 80, no. 1, pp. 17-21, 2003.

[10] O. O. Awolu, R. O. Osemeke, and B. O. T. Ifesan, "Antioxidant, functional and rheological properties of optimized composite flour, consisting wheat and amaranth seed, brewers' spent grain and apple pomace," Journal of Food Science and Technology, vol. 53, no. 2, pp. 1151-1163, 2016.

[11] S. I. Mussatto, G. Dragone, and I. C. Roberto, "Brewers' spent grain: generation, characteristics and potential applications," Journal of Cereal Science, vol. 43, no. 1, pp. 1-14, 2006.

[12] A. C. Fărcaş, S. A. Socaci, M. Tofană et al., "Nutritional properties and volatile profile of brewer's spent grain supplemented bread," Romanian Biotechnological Letters, vol. 19, no. 5, pp. 9705-9714, 2014.

[13] D. M. Waters, F. Jacob, J. Titze, E. K. Arendt, and E. Zannini, "Fibre, protein and mineral fortification of wheat bread through milled and fermented brewer's spent grain enrichment," European Food Research and Technology, vol. 235, no. 5, pp. 767-778, 2012.

[14] P. Prasertsan, S. Prasertsan, and A. H. Kittikun, Recycling of Agro-Industrial Wastes through Cleaner Technology, Biotechnology, Encyclopedia of Life Support Systems (EOLSS), 2007.

[15] C. Schill and K. Munz, Spent grain - a valuable raw material for a high fiber food snack - value-added products in brewing by cooking extrusion, Specialist Article, Bühler AG Business unit Pasta \& Extruded Products, 2013, Extracted from: https://docplayer.net/48089050-Spent-grain-a-valuable-rawmaterial-for-a-high-fiber-food-snack.html.

[16] P. Forssell, H. Kontkanen, H. A. Schols et al., "Hydrolysis of brewers' spent grain by carbohydrate degrading enzymes," Journal of the Institute of Brewing, vol. 114, no. 4, pp. 306314, 2008.

[17] A. Aboltins and J. Palabinskis, "Engineering for rural development research in brewer's spent grain drying process," Engineering for Rural Development, vol. 5, pp. 20-22, 2015.

[18] P. Ainsworth, Ş. Ibanoğlu, A. Plunkett, E. Ibanoğlu, and V. Stojceska, "Effect of brewers spent grain addition and screw speed on the selected physical and nutritional properties of an extruded snack," Journal of Food Engineering, vol. 81, no. 4, pp. 702-709, 2007.

[19] J. Essien and I. Udotong, "Amino acid profile of biodegraded brewers spent grains (BSG)," Journal of Applied Sciences and Environmental Management, vol. 12, no. 1, pp. 7-9, 2010.

[20] S. Öztürk, Ö. Özboy, I. Cavidoğlu, and H. Köksel, "Effects of brewer's spent grain on the quality and dietary fibre content of cookies," Journal of the Institute of Brewing, vol. 108, no. 1, pp. 23-27, 2002.

[21] V. Stojceska, P. Ainsworth, A. Plunkett, and Ş. Ibanoğlu, “The effect of extrusion cooking using different water feed rates on the quality of ready-to-eat snacks made from food by-products," Food Chemistry, vol. 114, no. 1, pp. 226-232, 2009.

[22] T. D. Hadnađev, A. Torbica, and M. Hadnađev, "Rheological properties of wheat flour substitutes/alternative crops assessed by Mixolab," Procedia Food Science, vol. 1, pp. 328-334, 2011.

[23] AACC, Approved Methods of the American Association of Cereal Chemists, American Association of Cereal Chemists, St. Paul Minnesota, 10th edition, 2000.

[24] F. M. Makinde and R. Akinoso, "Physical, nutritional and sensory qualities of bread samples made with wheat and black sesame (Sesamum indicum Linn) flours," International Food Research Journal, vol. 21, no. 4, pp. 1635-1640, 2014.

[25] AOAC, Official Methods of Analysis, the Association of Official Analytical Chemists, Gaithersburg, MD, USA, 17th edition, 2000.

[26] A. Turek, K. Wieczorek, and W. M. Wolf, "Digestion procedure and determination of heavy metals in sewage sludge - an analytical problem," Sustainability, vol. 11, no. 6, p. 1753, 2019.

[27] S. Ganesh, F. Khan, M. K. Ahmed, P. Velavendan, N. K. Pandey, and U. Kamachi Mudali, "Spectrophotometric determination of trace amounts of phosphate in water and soil," Water Science and Technology, vol. 66, no. 12, pp. 26532658, 2012.

[28] D. S. Ikuomola, O. L. Otutu, D. D. Oluniran, and F. Yildiz, "Quality assessment of cookies produced from wheat flour and malted barley (Hordeum vulgare) bran blends," Cogent Food \& Agriculture, vol. 3, no. 1, p. 1293471, 2017.

[29] S. Senthilkumar, T. V. Viswanathan, A. D. Mercy, P. Gangadevi, K. Ally, and K. Shyama, "Chemical composition of brewery waste," Tamil Nadu Journal of Veterinary and Animal Sciences, vol. 6, pp. 49-51, 2010.

[30] P. C. Madubuike and T. C. Okolo, "Quality estimation of brewer's spent grains and its potential: a product of beer industries," The International Journal of Engineering and Science (IJES), vol. 5, no. 3, pp. 21-25, 2016.

[31] N. C. Steinmacher, F. A. Honna, A. V. Gasparetto, D. Anibal, and M. V. E. Grossmann, "Bioconversion of brewer's spent grains by reactive extrusion and their application in breadmaking," LWT - Food Science and Technology, vol. 46, no. 2, pp. 542-547, 2012.

[32] J. Ahmed and L. Thomas, "Effect of $\beta$-glucan concentrate on the water uptake, rheological and textural properties of wheat flour dough," International Journal of Food Properties, vol. 18, no. 8, pp. 1801-1816, 2015.

[33] S. M. Bhatt and R. K. Gupta, "Bread (composite flour) formulation and study of its nutritive, phytochemical and functional properties," Journal of Pharmacognosy and Phytochemistry, vol. 4, no. 2, pp. 254-268, 2015.

[34] R. Mongi, B. K. Ndabikunze, B. E. Chove, P. Mamiro, C. C. Ruhembe, and J. G. Ntwenya, "Proximate composition, bread characteristics and sensory evaluation of cocoyam-wheat composite breads," African Journal of Food Agriculture Nutrition and Development, vol. 11, no. 48, pp. 5586-5599, 2011.

[35] M. Mudau, S. E. Ramashia, M. E. Mashau, and H. Silungwe, "Physicochemical characteristics of bread partially substituted with finger millet (Eleusine corocana) flour," Brazilian Journal of Food Technology, vol. 24, pp. 1-14, 2021.

[36] T. Amoriello, F. Mellara, V. Galli, M. Amoriello, and R. Ciccoritti, "Technological properties and consumer acceptability of bakery products enriched with brewers' spent grains," Food, vol. 9, no. 10, p. 1492, 2020. 
[37] A. Ktenioudaki, V. Chaurin, S. F. Reis, and E. Gallagher, "Brewer's spent grain as a functional ingredient for breadsticks," International Journal of Food Science and Technology, vol. 47, no. 8, pp. 1765-1771, 2012.

[38] P. Mello, G. Ishida, and C. J. Steel, "Physicochemical and sensory characteristics of pan bread samples available in the Brazilian market," Food Science and Technology, vol. 34, no. 4, pp. 746-754, 2014.

[39] K. S. Aplevicz, P. J. Ogliari, and E. S. Sant'Anna, "Influence of fermentation time on characteristics of sourdough bread," Brazilian Journal of Pharmaceutical Sciences, vol. 49, no. 2, pp. 233-239, 2013.

[40] U. K. Ibrahim, N. A. A. Rahman, M. U. H. Suzihaque, S. A. Hashib, and R. A. A. Aziz, "Effect of baking conditions on the physical properties of bread incorporated with green coffee beans (GCB)," IOP Conference Series: Materials Science and Engineering, vol. 736, no. 6, p. 062019, 2020.

[41] R. A. Siddiqi, D. S. Sogi, and P. K. Sehajpal, "Effect of shortterm sourdough fermentation on wheat protein," Cogent Food \& Agriculture, vol. 2, no. 1, pp. 1-10, 2016.

[42] R. Musa, O. Elawad, T. A. Yang et al., "Chemical composition and functional properties of wheat bread containing wheat and legumes bran," International Journal of Food Science and Nutrition, vol. 1, no. 5, pp. 10-15, 2016.

[43] O. P. Sobukola, J. M. Babajide, and O. Ogunsade, "Effect of brewers spent grain addition and extrusion parameters on some properties of extruded yam starch-based pasta," Journal of Food Processing and Preservation, vol. 37, no. 5, pp. 734743, 2013.

[44] C. N. Day and R. O. Morawicki, "Effects of fermentation by yeast and amylolytic lactic acid bacteria on grain sorghum protein content and digestibility," Journal of Food Quality, vol. 2018, 8 pages, 2018.

[45] S. G. Nkhata, E. Ayua, E. H. Kamau, and J. B. Shingiro, "Fermentation and germination improve nutritional value of cereals and legumes through activation of endogenous enzymes," Food Science \& Nutrition, vol. 6, no. 8, pp. 24462458, 2018.

[46] S. Ikram, L. Huang, H. Zhang, J. Wang, and M. Yin, "Composition and nutrient value proposition of brewers spent grain," Journal of Food Science, vol. 82, no. 10, pp. 2232-2242, 2017.

[47] M. K. Sharif, M. S. Butt, F. M. Anjum, and H. Newaz, "Preparation of fiber and mineral enriched defatted rice bran supplemented cookies," Pakistan Journal of Nutrition, vol. 8, no. 5, pp. 571-577, 2009.

[48] S. Tizazu, K. Urga, A. Belay, C. Abuye, and N. Retta, "Effect of germination on mineral bioavailability of sorghum-based complementary foods," African Journal of Food Agriculture Nutrition and Development, vol. 11, no. 5, pp. 5083-5095, 2011.

[49] M. B. Buta and S. A. Emire, "Effects of fermentation on the nutritional quality of QPM and soybean blends for the production of weaning food," Journal of Food Processing \& Technology, vol. 6, no. 11, 2015.

[50] A. O. Ojokoh, M. K. Daramola, and O. J. Oluoti, "Effect of fermentation on nutrient and anti-nutrient composition of breadfruit (Treculia africana) and cowpea (Vigna unguiculata) blend flours," African Journal of Agricultural Research, vol. 8, no. 27, pp. 3566-3570, 2013.

[51] M. C. N. Assohoun, T. N. Djeni, M. Koussémon-Camara, and K. Brou, "Effect of fermentation process on nutritional compo- sition and aflatoxins concentration of dokulu; a fermented maize based food," Food and Nutrition Sciences, vol. 4, no. 11, pp. 1120-1127, 2013.

[52] J. Lukinac, M. Jukić, F. Č. Kenjerić, P. Kolak, T. Efendić, and D. K. Komlenić, "Browning development in bakery products enriched with food industry by-products," in Proceedings of the 8th International Congress FLOUR-BREAD 2015 - 10th Croatian Congress of Cereal Technologists, pp. 55-65, Opatija, Croatia, 2015.

[53] K. O. Ajanaku, F. A. Dawodu, C. O. Ajanaku, and O. C. Nwinyi, "Functional and nutritional properties of spent grain enhanced cookies," American Journal of Food Technology, vol. 6, no. 9, pp. 763-771, 2011.

[54] N. Prentice and B. L. D’Appolonia, "High-fiber cookies containing brewers' spent grain," Cereal Chemistry, vol. 55, no. 5, pp. 712-721, 1977.

[55] E. G. Gimblet, A. F. Marney, and R. W. Bonsnes, "Determination of calcium and magnesium in serum, urine, diet, and stool by atomic absorption spectrophotometry," Jornal of Clinical Chemistry, vol. 13, no. 3, pp. 204-214, 1967.

[56] J. S. Petrović, B. S. Pajin, S. D. K. Tanackov, J. D. Pejin, and Z. Aleksandar, "Quality properties of cookies supplemented with fresh brewer's spent grain," Food and Feed Research, vol. 44, no. 1, pp. 57-63, 2017.

[57] W. Kunze, Technology Brewing and Malting. Third International Edition, VLB Berlin, Germany, 2004. 